НАУКОВИЙ ВІСНИК

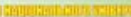

Taminoif

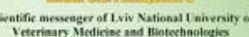

7

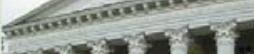

DIIIM

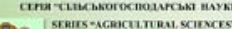

Toм 21 Nes 90

2019
Науковий вісник Дьвівського національного університету ветеринарної медицини та біотехнологій імені С.3. Гжицького. Серія: Сільськогосподарські науки

Scientific Messenger of Lviv National University of Veterinary Medicine and Biotechnologies. Series: Agricultural sciences

\title{
Milk productivity of cows-daughters from different bulls
}

\author{
S.I. Fyl ${ }^{1}$, E.I. Fedorovych ${ }^{2}$, P.V. Bodnar ${ }^{3}$ \\ ${ }^{1}$ Institute of Animal Breeding and Genetics nd. a. M.V. Zubets of National Academy of Agrarian Science of Ukraine \\ ${ }^{2}$ Institute of animal biology NAAS, Lviv, Ukraine \\ ${ }^{3}$ Stepan Gzhytskyi National University of Veterinary Medicine and Biotechnologies Lviv, Ukraine
}

Article info

Received 13.02.2019

Received in revised form 15.03.2019

Accepted 18.03.2019

Institute of Animal Breeding and Genetics nd. a. M.V. Zubets of National Academy of Agrarian Science of Ukraine, Pohrebnyaka Str., 1, Chubynske, Boryspil region, Kyiv district, 08321, Ukraine

Institute of animal biology NAAS, Vasyl Stus Str., 38, Lviv, 79034, Ukraine. Tel.: +38-032-270-23-89 E-mail:logir@ukr.net

Stepan Gzhytskyi National University of Veterinary Medicine and Biotechnologies Lviv, Pekarska Str., 50, Lviv, 79010, Ukraine.
Fyl, S.I., Fedorovych, E.I., \& Bodnar, P.V. (2019). Milk productivity of cows-daughters from different bulls.Scientific Messenger of Lviv National University of Veterinary Medicine and Biotechnologies. Series: Agricultural sciences, 21(90), 68-75. doi: 10.32718/nvlvet-a9012

The results of researches of signs of milk productivity of the cows from different bulls for the first, second, third and higher lactations are presented. Studies were conducted on Black-and-White cattle $(n=$ 1981) at Private Joint Stock Company "Plemzavod Styepnoy" Zaporizhia Oblast. There was studied the duration of lactation, milk yields of full and 305 days of lactation, fat and protein content in milk, quantity of milk fat and milk protein of descendants of different parents on the basis of a retrospective analysis of data for the period from 2004 to 2017 (the management program of the dairy herd "Uniform-Agri"). It was established that bulls have a significant impact on the formation of milk productivity of cows. Daughters of E. Naitinhel 683403608 had the longest duration of the first, second and higher lactation and descendants of N. Ardent 137922325 of the third one. Daughters of the bull G. Dzhungl 7816598 were the best by the milk yield of the full first and higher lactation, daughters E. Naitinhel 683403608 for the full second, and daughters of N. Ardent 137922325 - for the third. For 305 days of lactating there was observed a significant level of intergroup differentiation for the number of milk yield, milk fat and milk protein and much less by the amount of fat and protein in milk. For the first 305 days of lactation daughters of bull L.H.F. Bay $66821678(10188.0 \pm 377.12 \mathrm{~kg})$ were characterized by the highest milk yield, and daughters of F. Gailuron 103356429 (correspondingly 11028.8 $\pm 30619 ; 11643.3 \pm 590.20$ and $10311.7 \pm 382.07 \mathrm{~kg}$ ) for the second, third and the highest lactation, with both bulls belonging to the line R.O.R.E. Eleveyshn 1491007. For 305 days of the first lactation descendants of the bulls $V$. Silas 7419933 (7003.5 $\pm 317.79 \mathrm{~kg})$ from the line H.H. Starbak 352790 had the lowest milk yield, daughters of E. Naitinhel 683403608 (7633.0 \pm 182.18 ; $7605.8 \pm 224.58$ and $8491.7 \pm 185.42 \mathrm{~kg}$ respectively) from the line R.O.R.E. Eleveyshn 1491007 by the second, third and highest lactation. Detected by comparison of group average conditionality of phenotypic variability quantitative characteristics of the milk productivity of cows derived from different parents was confirmed by the dispersion analysis conducted by us. The most significant influence of bulls were made on the milk yields of daughters for the first-third lactation (12.9-16.8\%), lower - for the amount of milk fat $(12.4-15.6 \%)$ and milk protein (12.2-15.8\%) and even lower - for the content of fat (2.5-4.2\%) and protein in milk (3.7-6.6\%). It should be noted that the effect of the bulls on signs of milk productivity for the lactation under study in their daughters in almost all cases was reliable ( $P$ \& lt; 0.05-0.001) except for the fat content in milk for the first lactation and fat and protein - for the second and third lactation.

Key words: cows, daughters, bulls, lactation, milk yield, fat and protein content in milk, milk fat, milk protein, strength of influence.

\section{Молочна продуктивність корів-дочок різних бугаїв-плідників}

\author{
С.I. Филь ${ }^{1}$, С.I. Федорович ${ }^{2}$, П.В. Боднар ${ }^{3}$ \\ ${ }^{1}$ Інститут розведення $і$ генетики тварин імені М. В. Зубияя НААН, с. Чубинське, Бориспільський р-н \\ Київька обл., Украӥна \\ ${ }^{2}$ Інститут біології тварин НААН, м. Львів, Україна \\ ${ }^{3}$ Львівський національний університет ветеринарної медицини та біотехнологій імені С.3. Гжицького,
}




\section{м. Львів, Украӥна}

Наведено результати досліджень ознак молочної продуктивності корів, що походили від різних бугаїв-плідників, за першу, другу, третю та вищу лактації. Дослідження проведені на чорно-рябій худобі $(n=1981)$ в ПАТ “Племзавод “Стєпной”” Запорізькоі області. У потомків різних батьків на основі ретроспективного аналізу даних за період з 2004 по 2017 рр. (програма управління молочним стадом "Юніформ-Агрі") вивчали тривалість лактації, надій за повну та 305 днів лактації, вміст у молочі жиру та білка, кількість молочного жиру та молочного білка. Встановлено, що на формування молочної продуктивності корів значний вилив мають бугаї-плідники. Найдовшою тривалістю першої, другої і вищої лактачії відзначалися дочки бугая Е. Найтінгела 683403608, третьої - потомки Н. Ардента 137922325. За надоєм за повну периу та вищу лактаиії крашими виявилися дочки плідника Г. Дюсунгла 7816598, за повну другу - дочки Е. Найтінгела 683403608 і третю - дочки Н. Ардента 137922325. Суттєвий рівень міжгрупової диферениіації спостерігався за надоями, кількістю молочного жиру та молочного білка $і$ значно менший - за вмістом жиру й білка в молочі за 305 днів досліджуваних лактацій. Найвищими надоями за 305 днів першої лактації характеризу-

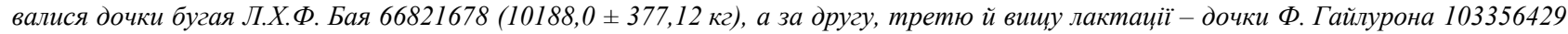

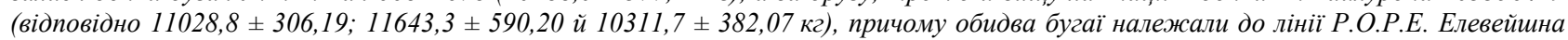
1491007. Найнижчі ж надої за 305 днів першої лактаиії були відмічені у потомків плідника В. Сіласа 7419933 (7003,5 $\pm 317,79$ кг) 3 лінії X.X. Старбака 352790, другої, третьої і вищої лактаиій - у дочок бугая Е. Найтінгела $683403608(7633,0 \pm 182,18 ; 7605,8 \pm$ 224,58 і 8491,7 $\pm 185,42$ кг відповідно) з лінії Р.О.Р.Е. Елевейшна 1491007. Виявлену порівнянням групових середніх зумовленість фенотипової мінливості кількісних ознак молочної продуктивності корів, що походять від різних батьків, підтверджено проведеним нами дисперсійним аналізом Найсуттевіший вплив бугаї справляли на надій дочок за першу-третю лактаиії (12,9-16,8\%), дещо менший - на кількість молочного жиру $(12,4-15,6 \%)$ та молочного білка $(12,2-15,8 \%)$ і ще менший - на вміст жиру (2,54,2\%) й білка в молочі (3,7-6,6\%). Слід відмітити, що вплив бугаїв на ознаки молочної продуктивності за досліджувані лактації у їх дочок майже у всіх випадках був достовірним $(P<0,05-0,001)$ за винятком вмісту жиру в молоиі за периу лактаџію та жиру й білка - за другу та третю лактациї.

Ключові слова: корови, дочки, бугаї-плідники, лактачія, надій, вміст жиру й білка в молочі, молочний жир, молочний білок, сила виливу.

\section{Вступ}

Забезпечення конкурентоспроможності та рентабельності молочної худоби за умов формування ринкових відносин в Україні грунтується на підвищенні генетичного потенціалу продуктивності тварин засобами селекції та створенням оптимальних умов вирощування, годівлі й утримання задля найбільш повної його реалізації (Koval, 2017). Серед найважливіших ланок селекційного удосконалення молочної худоби чи не найголовніше місце належить інтенсивному використанню бугаїв-плідників з високою племінною цінністю, оскільки багатьма вченими доведено суттєвий вплив на молочну продуктивність корів племінної цінності та лінійної належності їх батьків (Poslavska \& Fedorovych, 2015; Shcherbatyj \& Bodnar, 2015; Vechorka et al., 2018).

Сучасне поголів'я української чорно-рябої молочної породи формувалося з використанням голштинських бугаїв-плідників, внесок яких у створення і покращення породи відображається у пї генеалогічній структурі. Адже переважна частина ліній має голштинське походження. Тому оцінка тварин різних ліній та потомків бугаїв-плідників за основними господарськи корисними ознаками є одним із актуальних питань підвищення ступеня реалізації генетичного потенціалу тварин в конкретних умовах розведення та формування високопродуктивних і рентабельних стад молочної худоби (Ilyashenko \& Polupan, 2009; Stavetska \& Rudyk, 2011; Shulyar, 2018).

Відомо, що понад 90\% ефекту селекції забезпечується використанням цінних бугаїв-поліпшувачів. Однак, плідники відрізняються за стійкістю передачі спадкової інформації своїм потомкам, тобто препотентністю. Не всі бугаї однаково передають дочкам свої генетичні задатки господарськи корисних ознак у певному і взаємному їх поєднанні, а тим паче, в бажаному (Pidpala \& Bondar, 2017).
3 огляду на зазначене, метою наших досліджень було вивчити показники молочної продуктивності корів, що походили від різних батьків.

\section{Матеріал і методи досліджень}

Дослідження проведені на чорно-рябій худобі ПАТ "Племзавод “Стєпной”" Кам'янськоДніпровського району Запорізької області $(\mathrm{n}=1981)$. У корів-дочок різних бугаїв-плідників на основі ретроспективного аналізу даних за період з 2004 по 2017 рр. (програма управління молочним стадом “Юніформ-Агрі”) вивчали показники молочної продуктивності (надій за повну та 305 днів лактації, вміст у молоці жиру та білка, кількість молочного жиру та білка) за першу, другу, третю та вищу лактації. Приналежність бугаїв до ліній визначали за допомогою системи управління молочним скотарством СЦ “Інтесел Орсек”.

Отримані результати досліджень обробляли методом варіаційної статистики за Г.Ф. Лакиным (Lakyn, 1990) 3 використанням комп'ютерної програми "Excel”, а силу впливу батька на показники молочної продуктивності корів - методом однофакторного дисперсійного аналізу за допомогою програми "Statistica 6.1". Різницю між середніми значеннями вважали статистично вірогідною при Р $<0,05$ ( ${ }^{1}$ або $\left.{ }^{*}\right)$, $\mathrm{P}<0,01\left({ }^{2}\right.$ або $\left.{ }^{* *}\right), \mathrm{P}<0,001\left({ }^{3}\right.$ або $\left.{ }^{* * *}\right)$.

\section{Результати та їх обговорення}

Результати наших досліджень свідчать, що з поміж підконтрольного поголів'я корів найдовшою тривалістю першої лактації відзначалися дочки бугая Е. Найтінгела (табл. 1). За цим показником вони переважали потомків інших плідників на 18,3-168,8 дня, при цьому ця перевага вірогідною $(\mathrm{P}<0,05-0,01)$ була у більшості випадків. 


\section{Таблиця 1}

Молочна продуктивність дочок різних бугаїв-плідників за першу лактацію, $\mathrm{M} \pm \mathrm{m}$

\begin{tabular}{|c|c|c|c|c|c|c|c|c|}
\hline \multirow[b]{2}{*}{ Кличка та інв. № бугая } & \multirow[b]{2}{*}{$\mathrm{n}$} & \multicolumn{7}{|c|}{ Молочна продуктивність } \\
\hline & & $\begin{array}{c}\text { тривалість } \\
\text { лактації, днів }\end{array}$ & $\begin{array}{c}\text { надій за повну } \\
\text { лактацію, кг }\end{array}$ & $\begin{array}{c}\text { надій за } 305 \text { днів } \\
\text { лактації, кг }\end{array}$ & $\begin{array}{l}\text { вміст жиру } \\
\text { в молоці, \% }\end{array}$ & $\begin{array}{c}\text { вміст білка в } \\
\text { молоці, \% }\end{array}$ & $\begin{array}{c}\text { кількість } \\
\text { молочного } \\
\text { жиру, кг }\end{array}$ & $\begin{array}{c}\text { кількість } \\
\text { молочного } \\
\text { білка, кг }\end{array}$ \\
\hline \multicolumn{9}{|c|}{ Лінія К.М.І. Белла 1667366} \\
\hline С. Стейді 7746123 & 26 & $350,0 \pm 17,08^{3}$ & $10526,0 \pm 524,69$ & $9282,5 \pm 265,14^{1}$ & $3,75 \pm 0,043$ & $3,18 \pm 0,018$ & $348,5 \pm 10,88$ & $295,1 \pm 8,69$ \\
\hline Ф. Ломакс 10785322 & 52 & $362,1 \pm 13,32^{3}$ & $10089,1 \pm 489,29$ & $8625,4 \pm 279,01^{3}$ & $3,75 \pm 0,035$ & $3,19 \pm 0,014$ & $325,0 \pm 11,93^{2}$ & $274,9 \pm 8,88^{2}$ \\
\hline $\begin{array}{l}\text { Л.М. Мальво } \\
139205420\end{array}$ & 40 & $326,4 \pm 8,95^{3}$ & $10174,0 \pm 413,84$ & $9487,7 \pm 281,21$ & $3,71 \pm 0,032^{1}$ & $3,17 \pm 0,013^{1}$ & $352,6 \pm 11,12$ & $300,3 \pm 8,98$ \\
\hline Р. Самуело 207184648 & 111 & $446,9 \pm 14,44$ & $10738,9 \pm 304,84$ & $8122,1 \pm 124,90^{3}$ & $3,76 \pm 0,027$ & $3,20 \pm 0,010$ & $305,4 \pm 5,31^{3}$ & $259,6 \pm 4,00^{3}$ \\
\hline В середньому по лінї & 229 & 395,6 & $5 \pm 205,89$ & $8606,7 \pm 110,28$ & $3,75 \pm 0,017$ & 3,19 & $323,0 \pm 4,54$ & $274,2 \pm 3,51$ \\
\hline \multicolumn{9}{|c|}{ Лінія С.В.Д. Валіанта 1650414} \\
\hline С. Сідней 9428124 & 67 & $407,9 \pm 16,67^{1}$ & $10229,2 \pm 344,61$ & $8444,4 \pm 204,81^{3}$ & $3,78 \pm 0,033$ & $3,18 \pm 0,012^{1}$ & $319,5 \pm 8,84^{3}$ & $268,3 \pm 6,59^{3}$ \\
\hline $\begin{array}{l}\text { Роллінгстоунг } \\
103294329\end{array}$ & 96 & $383,1 \pm 10,47^{3}$ & $9623,8 \pm 298,56^{1}$ & $8033,2 \pm 164,40^{3}$ & $3,75 \pm 0,024$ & $3,18 \pm 0,010^{1}$ & $301,1 \pm 6,34^{3}$ & $255,0 \pm 5,30^{3}$ \\
\hline Г. Унгут 7352184 & 69 & $392,0 \pm 16,55^{2}$ & $10284,0 \pm 412,68$ & $8430,8 \pm 156,89^{3}$ & $3,76 \pm 0,042$ & $3,19 \pm 0,012$ & $316,7 \pm 6,51^{3}$ & $268,8 \pm 4,91^{3}$ \\
\hline В. Слеман 7817774 & 24 & $360,3 \pm 19,05^{3}$ & $9851,9 \pm 641,08$ & $8397,4 \pm 348,15^{3}$ & $3,78 \pm 0,045$ & $3,19 \pm 0,020$ & $316,5 \pm 12,94^{2}$ & $266,9 \pm 10,51^{3}$ \\
\hline К. Бонайр 9324236 & 26 & $400,1 \pm 23,62^{1}$ & $9866,3 \pm 754,78$ & $7985,5 \pm 322,29^{3}$ & $3,77 \pm 0,052$ & $3,21 \pm 0,019$ & $299,2 \pm 11,09^{3}$ & $255,8 \pm 10,19^{3}$ \\
\hline $\begin{array}{l}\text { В.Е.Д. Судан } \\
62768990\end{array}$ & 87 & $327,3 \pm 5,90^{3}$ & 1046 & 994 & 31 & $3,15 \pm 0,011^{3}$ & $374,1 \pm 7,52$ & 3 \\
\hline В середньому по лінї & 369 & $375,8 \pm 5,86$ & $10088,0 \pm 151,69$ & $8653,7 \pm 91,71$ & $3,76 \pm 0,014$ & $3,17 \pm 0,005$ & $325,4 \pm 3,64$ & $274,4 \pm 2,88$ \\
\hline \multicolumn{9}{|c|}{ Лінія Р.О.Р.Е. Елевейшна 1491007} \\
\hline Р. Бачелор 61690982 & 59 & $384,0 \pm 14,52^{3}$ & $9743,7 \pm 372,99^{1}$ & $7996,1 \pm 238,88^{3}$ & $3,73 \pm 0,034^{1}$ & $3,18 \pm$ & $299,2 \pm 9,63^{3}$ & $254,6 \pm 7,81^{3}$ \\
\hline Г. Твістер 7418701 & 48 & $397,6 \pm 15,07^{2}$ & $9305,9 \pm 430,15^{1}$ & $7638,7 \pm 268,10^{3}$ & $3,76 \pm 0,031$ & $3,21 \pm 0,016$ & $286,4 \pm 9,83^{3}$ & $245,1 \pm 8,79^{3}$ \\
\hline Б.Р. Гармоні 9498163 & 56 & $428,8 \pm 19,17$ & $10674,2 \pm 450,11^{1}$ & $8385,3 \pm 190,24^{3}$ & $3,74 \pm 0,036$ & $3,17 \pm 0,013^{1}$ & $314,4 \pm 8,44^{3}$ & $265,7 \pm 6,26^{3}$ \\
\hline Л.Х.Ф. Бай 66821678 & 28 & $326,8 \pm 9,53^{3}$ & $10874,0 \pm 476,73$ & $10188,0 \pm 377,12$ & $3,68 \pm 0,037^{2}$ & $3,15 \pm 0,021^{2}$ & $375,2 \pm 14,52$ & $319,6 \pm 11,18$ \\
\hline $\begin{array}{l}\text { Ф. Гайлурон } \\
103356429\end{array}$ & 39 & $380,8 \pm 15,17^{3}$ & $11097,3 \pm 541,28$ & $9160,7 \pm 307,54^{1}$ & $3,75 \pm 0,045$ & $3,17 \pm 0,013^{1}$ & $344,5 \pm 13,05$ & $290,0 \pm 9,76^{1}$ \\
\hline $\begin{array}{l}\text { М. Маніфолд } \\
135747713\end{array}$ & 56 & $420,0 \pm 18,08^{1}$ & $10115,6 \pm 438,44$ & $7982,3 \pm 21$ & $3,86 \pm 0,036$ & $3,18 \pm 0,015$ & $306,7 \pm 8,23^{3}$ & $253,1 \pm 6,75^{3}$ \\
\hline $\begin{array}{l}\text { Е. Найтінгел } \\
683403608\end{array}$ & 91 & 469 & $98^{1}$ & $48^{3}$ & 35 & 3,20 & 275,0 & $230,6 \pm 4,62^{3}$ \\
\hline В середньому по лінії & 377 & $413,7 \pm 7,00$ & $10138,2 \pm 169,99$ & $8097,4 \pm 94,86$ & $3,78 \pm 0,014$ & $3,18 \pm 0,005$ & $305,4 \pm 3,71$ & $257,5 \pm 3,01$ \\
\hline \multicolumn{9}{|c|}{ Лінія Х.Х. Старбака 352790} \\
\hline$\overline{\text { Л. Кінг }}$ & 43 & $385,4 \pm 19,78^{2}$ & $10082,3 \pm 497,44$ & $8340,6 \pm 296,16^{3}$ & 3,7 & & 311,8 & 266,4 \\
\hline В. Сілас 7419933 & 22 & $402,6 \pm 31,29^{1}$ & $8862,4 \pm 805,19^{1}$ & $7003,5 \pm 317,79^{3}$ & $3,87 \pm 0,064$ & $3,19 \pm 0,021$ & $270,9 \pm 12,62^{3}$ & $223,5 \pm 10,52^{3}$ \\
\hline $\begin{array}{l}\text { С. Клевеланд } \\
50840841\end{array}$ & 72 & $399,2 \pm 18,81^{2}$ & $9726,5 \pm 411,23^{1}$ & $7815,9 \pm 178,70^{3}$ & $3,80 \pm 0,032$ & $3,17 \pm 0,012^{2}$ & $296,5 \pm 6,88^{3}$ & $247,5 \pm 5,72^{3}$ \\
\hline Р.Л. Легенд 139164598 & 28 & $317,5 \pm 8,35^{3}$ & $9421,2 \pm 582,52^{1}$ & $8796,6 \pm 471,09^{1}$ & $3,78 \pm 0,051$ & $3,15 \pm 0,033$ & $332,8 \pm 18,51$ & $276,3 \pm 14,28^{1}$ \\
\hline $\begin{array}{l}\text { М.С. Спартен } \\
70098604\end{array}$ & 15 & $300,5 \pm 3,41^{3}$ & $10150,5 \pm 459,39$ & $10050,7 \pm 474,98$ & $3,69 \pm 0,044^{1}$ & $3,11 \pm 0,025^{3}$ & $369,8 \pm 16,60$ & $311,8 \pm 13,31$ \\
\hline Г. Джунгл 7816598 & 15 & $413,8 \pm 36,58$ & $12844,4 \pm 1406,49$ & $9481,3 \pm 350,27$ & $3,76 \pm 0,081$ & $3,16 \pm 0,016^{2}$ & 15,81 & $299,1 \pm 10,75$ \\
\hline Г. Сам 8324379 & 24 & $413,7 \pm 27,27$ & $9273,3 \pm 538,38^{1}$ & $7337,4 \pm 216,17^{3}$ & $3,78 \pm 0,050$ & $3,18 \pm 0,015$ & $277,0 \pm 8,39^{3}$ & $233,5 \pm 6,94^{3}$ \\
\hline М. Нірвана 101709244 & 67 & $407,7 \pm 14,98^{2}$ & $10296,4 \pm 403,52$ & $8227,0 \pm 191,11^{3}$ & $3,72 \pm 0,028^{1}$ & $3,20 \pm 0,012$ & $306,2 \pm 7,47^{3}$ & $263,0 \pm 6,00^{3}$ \\
\hline В середньому по лінії & 286 & $388,2 \pm 7,85$ & $9964,9 \pm 203,96$ & $8189,0 \pm 107,58$ & $3,77 \pm 0,015$ & $3,18 \pm 0,006$ & $308,0 \pm 4,07$ & $259,8 \pm 3,34$ \\
\hline \multicolumn{9}{|c|}{ Лінія П.Ф.А. Чіфа 1427381} \\
\hline $\begin{array}{l}\text { Л.М. Аурора } \\
137002937\end{array}$ & 112 & $375,7 \pm 11,16^{3}$ & $10450,5 \pm 295,24$ & $8783,7 \pm 169,09^{3}$ & $3,76 \pm 0,025$ & $3,19 \pm 0,011$ & $330,4 \pm 6,65^{2}$ & $280,0 \pm 5,35^{2}$ \\
\hline Н. Ардент 137922325 & 43 & $367,0 \pm 14,46^{3}$ & $10767,6 \pm 466,95$ & $9147,2 \pm 273,42^{1}$ & 3,7 & 020 & 0,70 & $290,5 \pm 8,50^{1}$ \\
\hline В.В. Він 139956906 & 88 & $345,5 \pm 7,18^{3}$ & $10157,4 \pm 242,13$ & $9179,2 \pm 183,50^{1}$ & $3,69 \pm 0,025^{2}$ & $3,16 \pm 0,010^{3}$ & $338,5 \pm 7,02^{1}$ & $289,5 \pm 5,77^{1}$ \\
\hline К.А. Паркер 65258473 & 18 & $302,1 \pm 2,94^{3}$ & $10072,2 \pm 433,59$ & $9943,6 \pm 424,47$ & $3,71 \pm 0,043^{1}$ & $3,16 \pm 0,021^{1}$ & $368,8 \pm 16,84$ & $313,5 \pm 12,87$ \\
\hline М.В. Скотт 7677410 & 47 & $395,6 \pm 20,64^{2}$ & $8985,2 \pm 551,33^{2}$ & $7211,1 \pm 222,49^{3}$ & $3,84 \pm 0,041$ & $3,17 \pm 0,014^{1}$ & $276,3 \pm 8,75^{3}$ & $228,5 \pm 7,19^{3}$ \\
\hline Б. Рональд 6780909 & 28 & $451,0 \pm 29,54$ & $10960,6 \pm 588,92$ & $8318,6 \pm 253,57^{3}$ & $3,79 \pm 0,046$ & $3,18 \pm 0,020$ & $315,3 \pm 10,35^{3}$ & $264,9 \pm 8,31^{3}$ \\
\hline Б. Пагевайр 8641364 & 109 & $391,1 \pm 13,18^{3}$ & $10424,4 \pm 374,96$ & $8439,1 \pm 170,51^{3}$ & $3,78 \pm 0,023$ & $3,21 \pm 0,010$ & $318,7 \pm 6,70^{3}$ & $270,2 \pm 5,37^{3}$ \\
\hline Г. Тандем 9434213 & 104 & $390,4 \pm 11,94^{3}$ & $10255,7 \pm 279,99$ & $8604,9 \pm 137,56^{3}$ & $3,78 \pm 0,026$ & $3,18 \pm 0,010^{1}$ & $324,8 \pm 5,64^{3}$ & $273,9 \pm 4,49^{3}$ \\
\hline Х. Хіатт 60700461 & 36 & $392,3 \pm 20,46^{2}$ & $10073,0 \pm 551,06$ & $8284,3 \pm 264,44^{3}$ & $3,79 \pm 0,049$ & $3,16 \pm 0,019^{1}$ & $313,6 \pm 10,60^{3}$ & $262,1 \pm 8,61^{3}$ \\
\hline В.Б. Секвойя 64188829 & 36 & $368,0 \pm 15,49^{3}$ & $10692,9 \pm 435,32$ & $9483,6 \pm 316,08$ & $3,71 \pm 0,040^{1}$ & $3,16 \pm 0,017^{1}$ & $352,4 \pm 13,07$ & $298,9 \pm 9,99$ \\
\hline $\begin{array}{l}\text { Л. Марселлюс } \\
136057831\end{array}$ & 21 & $393,4 \pm 32,09^{1}$ & $10949,2 \pm 838,65$ & $8774,5 \pm 402,38^{1}$ & $3,70 \pm 0,047^{1}$ & $3,17 \pm 0,024$ & $324,3 \pm 14,99^{1}$ & $277,8 \pm 12,53^{1}$ \\
\hline В середньому по лінї & 642 & $379,7 \pm 4,72$ & $10308,7 \pm 125,11$ & $8682,8 \pm 69,51$ & $3,76 \pm 0,010$ & $3,18 \pm 0,004$ & $326,2 \pm 2,70$ & $275,8 \pm 2,20$ \\
\hline \multicolumn{9}{|c|}{ Лінія Дж. Бесна 5694028588} \\
\hline Карім 64541701 & 53 & $317,9 \pm 3,95^{3}$ & $9703,9 \pm 331,10^{1}$ & $9331,5 \pm 345,22$ & $3,69 \pm 0,030^{2}$ & $013^{3}$ & $344,5=$ & $292,4 \pm 10,56$ \\
\hline Інші батьки & 25 & $299,2 \pm 2,29$ & $9667,5 \pm 325,83$ & $9539,6 \pm 350,63$ & $3,73 \pm 0,044$ & $3,13 \pm 0,017$ & $355,6 \pm 13,69$ & $298,3 \pm 10,89$ \\
\hline
\end{tabular}

Примітка. У цій і наступних таблицях достовірність різниці досліджуваних показників вказана при порівнянні до найвищого значення

Найменше ж значення тривалості першої лактації було відмічено у дочок бугая М.С. Спартена. Коефіцієнт варіації названого показника у потомків підконтрольних плідників знаходився в межах 4,1-40,0\%.

За надоєм за повну першу лактацію кращими виявилися дочки бугая Г. Джунгла. Їх перевага за назва- ним показником над первістками, що походили від інших плідників, коливалася від 380,5 до 3982,0 кг, проте достовірною $(\mathrm{P}<0,05-0,01)$ вона була лише над дочками бугаїв Роллінгстоунга, Р. Бачелора, Г. Твістера, Б.Р. Гармоні, Е. Найтінгела, В. Сіласа, С. Клевеланда, Р.Л. Легенда, Г. Сама, М.В. Скотта та 
С.Дж. Каріма. Найменше молока за повну першу лактацію одержано від потомків бугая В. Сіласа 8862,4 кг. При цьому мінливість надою за вказану лактацію у дочок різних плідників була досить високою і знаходилася в межах 17,5-42,6\%. Дещо меншою варіабельністю відзначався надій первісток за 305 днів лактації i, залежно від походження за батьком, він коливався від 14,3 до 28,3\%. Найвищими надоями за 305 днів першої лактації характеризувалися дочки плідника Л.Х.Ф.Бая, а найнижчими - дочки бугая В. Сіласа. Різниця між ними за названим показником становила 3184,5 кг (P < 0,001), при цьому перші переважали потомків всіх решту плідників на 29,12988,3 кг.

Слід відмітити, що 3 поміж плідників лінії K.M.I. Белла 1667366 кращими за надоями за 305 днів першої лактації виявилися дочки бугая Л.М. Мальво, лінії С.В.Д. Валіанта 1650414 - дочки В.Е.Д. Судана, лінії Р.О.Р.Е. Елевейшна 1491007 - дочки Л.Х.Ф. Бая, лінії Х.Х. Старбака 352790 - дочки Л. Кінглі і лінії П.Ф.А. Чіфа 1427381 - дочки К.А. Паркера.

Дочки різних бугаїв-плідників відрізнялися між собою і за вмістом жиру в молоці. Цей показник у них знаходився в межах 3,78-3,87\%, причому найвище його значення спостерігалося у первісток, що походили від плідника В. Сіласа. Різниця між ними та потомками решту плідників коливалася від 0,01 до 0,19\%. Ще менша різниця між дочками різних бугаїв відмічена за вмістом білка в молоці - 0,01-0,10\%. Найвище його значення спостерігалося у тварин, які одержані від бугаїв-плідників К. Бонайра, Г. Твістера та Б. Пагевайра $(3,21 \%)$, а найменше - від первісток, що походять від бугая М.С. Спартена (3,11\%).

За кількістю молочного жиру та молочного білка за першу лактацію у дочок підконтрольних бугаїв спостерігалися такі ж тенденції, як і за надоєм, тобто найвищими ці показники були у дочок Л.Х.Ф. Бая, а найнижчими - у дочок В. Сіласа. Перші переважали дочок всіх інших плідників за названими показниками відповідно на 0,8-104,3 та 1,4-96,1 кг.

Встановлено, що найдовшою тривалістю другої лактації відзначалися дочки Е. Найтінгела, а найкоротшою - потомки Л.М. Мальво (табл. 2). Різниця між ними за цим показником становила 132,1 дня $(\mathrm{P}<0,001)$.

За надоєм за повну другу лактацію кращими виявилися дочки В. Слемана. Вони переважали потомків інших плідників за цим показником на 240,93645,5 кг. Найвищими надоями за 305 днів другої лактації відзначалися дочки Ф. Гайлурона. Їх перевага за названим показником над коровами, що походили від решту підконтрольних бугаїв, коливалася від 412,0 до 3395,8 кг, причому у більшості випадків вона була вірогідною. Надої як за повну, так і за 305 днів другої лактації відзначалися досить високою варіабельністю - 18,1-46,2 і 13,3-33,2\% відповідно.

Варто зазначити, що 3 поміж бугаїв лінії К.М.І. Белла 1667366 кращими надоями за 305 днів вищеназваної лактації характеризувалися дочки С. Стейді, лінії С.В.Д. Валіанта 1650414 - дочки В. Слемана, лінії Р.О.Р.Е. Елевейшна 1491007 - дочки Ф. Гайлурона, лінії Х.Х. Старбака 352790 - дочки

\section{Л. Кінглі і лінії П.Ф.А. Чіфа 1427381 - дочки Н. Ардента.}

У дочок різних бугаїв-плідників з другою лактацією різниця за вмістом жиру та білка в молоці була більш суттєвою, ніж за першу лактацію. Так, різниця між потомками досліджуваних плідників за вмістом жиру в молоці за другу лактацію знаходилася в межах 0,02-0,29, а за вмістом білка в молоці - в межах 0,03$0,13 \%$, причому перший показник найвищим був у дочок Г. Джунгла, а другий - у дочок В.В. Віна. Найнижчі ж значення вищеназваних ознак були відмічені відповідно у потомків Ф. Гайлурона та Л.М. Мальво.

За кількістю молочного жиру кращими виявилися дочки Л.М. Аурора. За цим показником вони переважали ровесниць, що походили від інших плідників на 2,7-118,0 кг. Різниця за кількістю молочного білка між потомками різних бугаїв коливалася від 7,6 до 102,6 кг. Найвищими значеннями названого показника характеризувалися дочки Ф. Гайлурона, а найнижчими - дочки Е. Найтінгела. Мінливість кількості молочного жиру та молочного білка у дочок підконтрольних бугаїв була досить високою і становила відповідно 13,0-34,0 та 14,5-33,5\%.

Результати наших досліджень свідчать, що тривалість лактації з віком корів зростала. Так, у повновікових корів (третя лактація) вона була значно довшою ніж за першу та другу лактації і коливалася від 330,9 до 521,8 дня (табл. 3). Найвище значення цього показника спостерігалося у дочок Н. Ардента. Їх перевага за названою ознакою над дочками решту бугаївплідників знаходилася в межах 14,3-190,9 дня. У дочок Н. Ардента відповідно були відмічені і найвищі надої за повну третю лактацію. Потомки, які походили від інших бугаїв поступалися їм за цим показником на 1746,9-7086,7 кг. Водночас за надоєм за 305 днів третьої лактації кращими виявилися дочки Ф. Гайлурона, а гіршими - Е. Найтінгела $з$ різницею між ними в 4037,5 кг (Р < 0,001). Перші за вищеназваною ознакою переважали решту ровесниць, що походили від інших батьків, на 143,3-3384,2 кг, причому ця перевага здебільшого була достовірною. Надої як за повну лактацію, так і за 305 днів характеризувалися досить високою варіабельністю - відповідно 18,542,2 та 13,3-33,2\%.

Слід відмітити, що з поміж корів лінії К.М.І. Белла 1667366 кращими за надоями за 305 днів лактації були дочки бугая Ф. Ломакса, лінії С.В.Д. Валіанта 1650414 - дочки В. Слемана, лінії Р.О.Р.Е. Елевейшна 1491007 - потомки Ф. Гайлурона, лінії Х.Х. Старбака 352790 - потомки С. Клевеланда та лінії П.Ф.А. Чіфа 1427381 - дочки Н. Ардента. Найнижчі ж значення надоїв за 305 днів третьої лактації серед корів наведених вище ліній спостерігалися відповідно у потомків плідників Р. Самуело, К. Бонайра, Е. Найтінгела, Г. Джунгла та Г. Тандема.

Щодо вмісту жиру в молоці корів 3 третьою лактацією, то різниця між дочками різних бугаїв хоч і знаходилася в межах 0,03-0,24\%, проте в жодному випадку не була вірогідною. Втім, за вмістом білка в молоці різниця між коровами різних груп майже в половина випадків була достовірною ( $<<0,05-0,01)$; вона знаходилася в межах 0,02-0,14\%. За першим показни- 
ком кращими виявилися дочки бугая К. Бонайра, а за другим - дочки Р. Бачелора, Л. Кінглі, Г. Сама та Л. Марселлюса. Найнижчий вміст жиру та білка в молоці відмічено у корів, народжених від плідників В. Сіласа та Г. Джунгла відповідно.

\section{Таблиця 2}

Молочна продуктивність дочок різних бугаїв-плідників за другу лактацію, $\mathrm{M} \pm \mathrm{m}$

\begin{tabular}{|c|c|c|c|c|c|c|c|c|}
\hline \multirow[b]{2}{*}{ Кличка та інв. № бугая } & \multirow[b]{2}{*}{$\mathrm{n}$} & \multicolumn{7}{|c|}{ Молочна продуктивність } \\
\hline & & $\begin{array}{c}\text { тривалість } \\
\text { лактації, днів }\end{array}$ & $\begin{array}{c}\text { надій за повну } \\
\text { лактацію, кг }\end{array}$ & $\begin{array}{c}\text { надій за } 305 \text { днів } \\
\text { лактації, кг }\end{array}$ & $\begin{array}{c}\text { вміст жиру в } \\
\text { молоці, \% }\end{array}$ & $\begin{array}{l}\text { вміст білка } \\
\text { в молоці, \% }\end{array}$ & $\begin{array}{c}\text { кількість } \\
\text { молочного } \\
\text { жиру, кг }\end{array}$ & $\begin{array}{c}\text { кількість } \\
\text { молочного } \\
\text { білка, кг }\end{array}$ \\
\hline \multicolumn{9}{|c|}{ Лінія К.М.І. Белла 1667366} \\
\hline . Стейді 77 & 12 & 77,72 & $195,0 \pm 1315,6 /$ & $10416,8 \pm 574,33$ & $3,79 \pm 0,124$ & $3,16=-2,4$ & $394,1 \pm 24,84$ & $328,8 \pm 18,15$ \\
\hline & 36 & & $11217,2 \pm 519,99$ & $9799,7 \pm 342,15^{2}$ & $3,74 \pm 0,046^{1}$ & & & \\
\hline Л.М & 6 & & $\pm 1085,29$ & & & & & 7,61 \\
\hline Р. Самуело 207184648 & 91 & $381,2 \pm 10,29^{2}$ & $9521,4 \pm 354,17^{3}$ & $8227,7 \pm 232,73^{3}$ & 0,034 & & $9,21^{3}$ & $7,68^{3}$ \\
\hline & & & $10256,6 \pm 290,97$ & $8888,7 \pm 193,57$ & & & & \\
\hline \multicolumn{9}{|c|}{ Лінія С.В.Д. Валіанта 1650414} \\
\hline 4 & 39 & & $10949,5 \pm 2$ & & 3,7 & & 50/,9 & 3 \\
\hline Рол & 57 & $1^{2}$ & $10992,8 \pm$ & & & & $2,61^{3}$ & \\
\hline & 49 & 1 & 120 & $9670,0 \pm 320,75^{2}$ & & & & \\
\hline & 15 & & 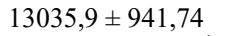 & 1046 & & & & \\
\hline & 17 & & 10099,1 & $8427,9 \pm 673,80^{3}$ & & & 320,2 & $89^{2}$ \\
\hline & 12 & 337,9 & 9863 & $6 \pm 508,61^{2}$ & & & & \\
\hline & & & 11273 & 9481 & & & & \\
\hline \multicolumn{9}{|c|}{ Лінія Р.О.Р.Е. Елевейшна 1491007} \\
\hline P. Б & 41 & & - & & 3,78 & & 2 & 2 \\
\hline & 33 & & 1000 & & & & & \\
\hline & 28 & & & & & & & \\
\hline & 23 & & $12383,6 \pm 512,29$ & 1102 & $062^{2}$ & & & \\
\hline & 38 & & $11094,8 \pm 412,02$ & & & & & 296 \\
\hline & 73 & & & & & & & \\
\hline & & & 54,90 & 881 & & & & \\
\hline \multicolumn{9}{|c|}{ Лінія Х.Х. Старбака 352790} \\
\hline & 36 & & & & & & & \\
\hline & 19 & $1^{2}$ & & & & & & \\
\hline & 6 & & & & & & & \\
\hline & 8 & & & & & & & \\
\hline & 17 & & & 866 & & & & \\
\hline & . & & 103 & 869 & & & & \\
\hline & & & 10 & 904 & & & & \\
\hline \multicolumn{9}{|c|}{ Лінія П.Ф.А. Чіфа 1427381} \\
\hline & & & $=363,36$ & $10588,1 \pm 174,67$ & & & & \\
\hline & 22 & & & & & & & \\
\hline & 7 & & & & & & & \\
\hline & 33 & 1 & $11291,5 \pm 8$ & $8995,5 \pm 406,97^{3}$ & & & 354 & $285,6 \pm 13,78^{3}$ \\
\hline 909 & 19 & 78 & $10164,6 \pm 909,46^{1}$ & $8527,8 \pm 523,49^{3}$ & $3,67 \pm$ & & $310,3 \pm 17,75^{3}$ & $267,9 \pm 16,71^{3}$ \\
\hline & 77 & & & $9786,9 \pm 280,96^{2}$ & & & & \\
\hline & 73 & 36 & $10794,6 \pm 430,24^{1}$ & $9498,8 \pm 293,72^{3}$ & $3,75 \pm 0$ & 3,19 & $354,8 \pm 11,27^{3}$ & 302,5 \\
\hline 461 & 28 & $356,8 \pm 16,83^{2}$ & $9702,8 \pm 603,62^{2}$ & $8633,9 \pm 425,53^{3}$ & $3,83 \pm 0,061$ & $3,20 \pm$ & $328,4 \pm 15$ & $276,0 \pm 13,46^{3}$ \\
\hline & 19 & $318,8 \pm 6,43^{3}$ & $10713,3 \pm 519,67^{1}$ & $10316,5 \pm 452,71$ & 83 & & & \\
\hline & 14 & & $9810,2 \pm 770,84^{1}$ & $9280,9 \pm 610,14^{2}$ & & $3,13=$ & $352,9 \pm 20,19^{1}$ & $290,8 \pm 19,06^{3}$ \\
\hline$B c e$ & 365 & $376,9 \pm 6$ & $11242,8 \pm 186,73$ & $9722,7 \pm 118,53$ & $\pm 0,016$ & $3,18 \pm 0$ & $368,3 \pm 4,67$ & $309,4 \pm 3,80$ \\
\hline Інші батьки & 4 & $472,3 \pm 34,29$ & $10105,3 \pm 390,35$ & $8378,0 \pm 346,07$ & $3,65 \pm 0,136$ & $3,15 \pm 0,0693$ & $306,3 \pm 20,33$ & $264,0 \pm 12,98$ \\
\hline
\end{tabular}

За кількістю молочного жиру та молочного білка спостерігалася така ж тенденція як і за надоєм за 305 днів лактації: найвищі значення цих ознак були у потомків Ф. Гайлурона, а найнижчі - у дочок Е. Найтінгела.

Аналіз даних свідчить, що найдовшою тривалістю вищої лактації відзначалися дочки бугая Е. Найтінгела - 497,1 дня, що більше ніж у потомків інших плідників на 1,8-196,6 дня (табл. 4). За повну вищу лактацію найбільше молока одержано від корів, які походили від бугая Г. Джунгла, а найменше - від особин, народжених від плідника Р.Л. Легенда. Різниця між ними за цим показником становила 3942,2 кг $(\mathrm{P}<0,01)$. Кращими ж за надоями за 305 днів вищої лактації виявилися потомки Ф. Гайлурона. Їх перевага за цією ознакою над коровами, що походили від решту підконтрольних плідників, коливалася від 64,1 до 1820,0 кг, однак вірогідною вона була лише у 14 випадках із 36. Мінливість надоїв за повну та 305 днів вищої лактації у дочок різних бугаїв була досить суттєвою і знаходилася відповідно в межах 17,5-42,3 та 14,4-39,3\%.

Вміст жиру в молоці за вищу лактацію у підконтрольного поголів'я корів коливався від 3,69 (дочки Л.Х.Ф. Бая) до $3,85 \%$ (дочки М.В. Скотта), а вміст білка - від 3,11 (дочки М.С. Спартена) до 3,22\% (дочки К. Бонайра). Різниця 3 цими показниками між дочками різних плідників становила відповідно 0,04-0,16 та $0,01-0,08 \%$. 
Таблиця 3

Молочна продуктивність дочок різних бугаїв-плідників за третю лактацію, $\mathrm{M} \pm \mathrm{m}$

\begin{tabular}{|c|c|c|c|c|c|c|c|c|}
\hline \multirow[b]{2}{*}{ Кличка та інв. № бугая } & \multirow[b]{2}{*}{$\mathrm{n}$} & \multicolumn{7}{|c|}{ Молочна продуктивність } \\
\hline & & $\begin{array}{c}\text { тривалість } \\
\text { лактації, днів }\end{array}$ & $\begin{array}{c}\text { надій за повну } \\
\text { лактацію, кг }\end{array}$ & $\begin{array}{c}\text { надій за } 305 \text { днів } \\
\text { лактації, кг }\end{array}$ & $\begin{array}{c}\text { вміст жиру в } \\
\text { молоці, \% }\end{array}$ & $\begin{array}{c}\text { вміст білка в } \\
\text { молоці, \% }\end{array}$ & $\begin{array}{c}\text { кількість } \\
\text { молочного } \\
\text { жиру, кг }\end{array}$ & $\begin{array}{c}\text { кількість } \\
\text { молочного } \\
\text { білка, кг }\end{array}$ \\
\hline \multicolumn{9}{|c|}{ Лінія К.М.І. Белла 1667366} \\
\hline С. Стейді 7746123 & 10 & $376,8 \pm 41,83^{1}$ & $11684,2 \pm 1334,61$ & $9896,6 \pm 785,20$ & $3,70 \pm 0,085$ & $3,17 \pm 0,021^{2}$ & $24,13^{1}$ & $313,5 \pm 24,97$ \\
\hline Ф. Ломакс 10785322 & 11 & $405,4 \pm 30,40$ & $12865,4 \pm 892,26$ & $10716,5 \pm 460,27$ & $3,80 \pm 0,097$ & $3,16 \pm 0,031^{1}$ & $405,1 \pm 15,11$ & $338,3 \pm 13,81$ \\
\hline Р. Самуело 207184648 & 53 & $383,2 \pm 18,53^{1}$ & $9974,9 \pm 541,91^{2}$ & $8537,3 \pm 356,18^{3}$ & $3,81 \pm 0,030$ & $3,23 \pm 0,014$ & $325,7 \pm 14,07^{3}$ & $275,2 \pm 11,52^{3}$ \\
\hline В середньому по лінії & 74 & $385,6 \pm 14,97$ & $10635,6 \pm 460,60$ & $9044,9 \pm 298,11$ & $3,79 \pm 0,028$ & $3,21 \pm 0,012$ & $342,3 \pm 11,26$ & $289,7 \pm 9,48$ \\
\hline \multicolumn{9}{|c|}{ Лінія С.В.Д. Валіанта 1650414} \\
\hline С.Сідней 9428124 & 14 & $364,9 \pm 24,59^{1}$ & $9488,1 \pm 767,80^{2}$ & $8649,9 \pm 555,68^{3}$ & $3,67 \pm 0,050$ & $3,18 \pm 0,034$ & $317,8 \pm 21,05^{3}$ & $274,6 \pm 17,48^{2}$ \\
\hline Роллінгстоунг 103294329 & 22 & $364,3 \pm 17,19^{2}$ & $11072,9 \pm 812,54^{1}$ & $9822,0 \pm 570,55^{1}$ & $3,82 \pm 0,063$ & $3,19 \pm 0,024$ & $375,4 \pm 22,82^{1}$ & $312,9 \pm 17,46^{1}$ \\
\hline Г. Унгут 7352184 & 25 & $371,2 \pm 18,74^{1}$ & $11274,3 \pm 706,65^{1}$ & $10044,6 \pm 553,36^{1}$ & $3,71 \pm 0,036$ & $3,17 \pm 0,021^{2}$ & $370,8 \pm 19,55^{1}$ & $317,8 \pm 17,33$ \\
\hline В. Слеман 7817774 & 9 & $348,4 \pm 30,97^{2}$ & $12043,9 \pm 989,89$ & $11500,0 \pm 829,11$ & $3,71 \pm 0,067$ & $3,12 \pm 0,054^{1}$ & $425,5 \pm 30,35$ & $356,8 \pm 23,45$ \\
\hline К. Бонайр 9324236 & 7 & $356,3 \pm 32,68^{1}$ & $9014,6 \pm 832,97^{3}$ & $8259,1 \pm 707,62^{3}$ & $3,88 \pm 0,131$ & $3,18 \pm 0,030$ & $320,4 \pm 27,94^{2}$ & $264,0 \pm 24,34^{2}$ \\
\hline В середньому по лінії & 77 & $364,1 \pm 9,91$ & $10776,5 \pm 387,60$ & $9735,2 \pm 299,00$ & $3,75 \pm 0,028$ & $3,17=$ & $364,3 \pm 11,18$ & $308,2 \pm 9,20$ \\
\hline \multicolumn{9}{|c|}{ Лінія Р.О.Р.Е. Елевейшна 1491007} \\
\hline 61690982 & 20 & 330 & $4 \pm 709,10^{3}$ & & $3,7 \mathrm{~s}$ & 31 & 326,0 & 3279 \\
\hline Г. Твістер 7418701 & 19 & $434,7 \pm 58,19$ & $12233,5 \pm 1045,23$ & $10017,3 \pm 556,92^{1}$ & $3,74 \pm 0,073$ & $3,22 \pm 0,029$ & 374,8 & 321,5 \\
\hline Б.Р. Гармоні 9498163 & 20 & $480,8 \pm 45,78$ & $12869,1 \pm 1006,83$ & $9990,7 \pm 519,74^{1}$ & $3,67 \pm 0,061$ & $3,20 \pm 0,016$ & $363,8 \pm 16,90^{2}$ & $318,9 \pm 16,13$ \\
\hline Ф. Гайлурон 103356429 & 9 & $464,3 \pm 48,87$ & $13930,1 \pm 1002,90$ & $11643,3 \pm 590,20$ & $3,80 \pm 0,121$ & $3,15 \pm 0,026^{2}$ & $442,1 \pm 25,37$ & $366,5 \pm 18,56$ \\
\hline М. Маніфолд 135747713 & 19 & $347,7 \pm 14,80^{2}$ & $11935,2 \pm 820,61^{1}$ & $10845,2 \pm 679,24$ & $3,72 \pm 0,037$ & $3,19 \pm 0,025$ & $403,4 \pm 25,51$ & $345,8 \pm 21,27$ \\
\hline Е. Найтінгел 683403608 & 52 & $404,0 \pm 17,62^{1}$ & $9069,8 \pm 391,29^{3}$ & $7605,8 \pm 224,58^{3}$ & $3,77 \pm 0,030$ & $3,19 \pm 0,014^{1}$ & $287,1 \pm 8,85^{3}$ & $242,7 \pm 7,15^{3}$ \\
\hline В середньому по лінії & 139 & $404,9 \pm 13,40$ & $10755,5 \pm 331,75$ & $9126,8 \pm 221,90$ & $3,75 \pm 0,021$ & $3,20 \pm 0,009$ & $341,7 \pm 8,40$ & $291,9 \pm 7,01$ \\
\hline \multicolumn{9}{|c|}{ Лінія Х.Х. Старбака 352790} \\
\hline Л. Кін & 17 & $384,1=$ & $1009,95^{1}$ & $9644,5 \pm 517,37^{2}$ & $3,82 \pm 0,066$ & 3,25 & 368 & 313,1 \\
\hline В. Сілас 7419933 & 13 & $401,6 \pm 35,47$ & $11512,2 \pm 1233,03^{1}$ & $9592,4 \pm 741,53^{1}$ & $3,64 \pm 0,044$ & $3,18 \pm 0,020^{1}$ & $348,7 \pm 27,35^{1}$ & $304,2 \pm 22,77^{1}$ \\
\hline С. Клевеланд 50840841 & 21 & $370,2 \pm 22,69^{1}$ & $12173,0 \pm 600,33^{1}$ & $11138,7 \pm 442,42$ & $3,77 \pm 0,063$ & 3,18 & $419,2 \pm 17,34$ & $353,8 \pm 13,62$ \\
\hline Г. Джунгл 7816598 & 3 & $342,3 \pm 19,70^{2}$ & $8767,7 \pm 1027,08^{3}$ & $8303,7 \pm 872,30^{2}$ & $3,68 \pm 0,062$ & $3,11 \pm 0,059^{1}$ & $304,2 \pm 27,44^{3}$ & $257,7 \pm 23,76^{2}$ \\
\hline Г. Сам 8324379 & 8 & $432,0 \pm 34,94$ & $13637,9 \pm 1205,02$ & $10846,0 \pm 508,41$ & $3,75 \pm 0,067$ & $3,25 \pm 0,035$ & $407,7 \pm 22,63$ & $351,4 \pm 14,55$ \\
\hline М. Нірвана 101709244 & 27 & $398,5 \pm 25,30^{1}$ & $10880,6 \pm 740,34^{2}$ & $9119,6 \pm 488,75^{2}$ & $3,77 \pm 0,048$ & $3,21 \pm 0,021$ & $343,7 \pm 18,90^{2}$ & $293,4 \pm 16,04^{2}$ \\
\hline В середньому по лінії & 89 & $390,6 \pm 12,88$ & $11536,2 \pm 394,31$ & $9893,0 \pm 250,98$ & $3,76 \pm 0,026$ & $3,21 \pm 0,013$ & $371,4 \pm 9,70$ & $317,0 \pm 7,96$ \\
\hline \multicolumn{9}{|c|}{ Лінія П.Ф.А. Чіфа 1427381} \\
\hline 137002937 & 30 & 389,6 & $, 0 \pm 758,23$ & $10554,1 \pm 348,29$ & 051 & & 398,6 & 338,6 \\
\hline Н. Ардент 137922325 & 10 & $521,8 \pm 56,17$ & $15854,4 \pm 1745,54$ & $11490,8 \pm 498,86$ & $3,77 \pm 0,096$ & $3,16 \pm 0,036^{1}$ & $431,8 \pm 16,96$ & $363,4 \pm 16,04$ \\
\hline М.В. Скотт 7677410 & 15 & $356,3 \pm 21,93^{2}$ & $10247,3 \pm 840,51^{2}$ & $9208,7 \pm 642,72^{2}$ & $3,73 \pm 0,061$ & $3,19 \pm 0,034$ & $344,9 \pm 25,60^{2}$ & $293,9 \pm 20,98^{1}$ \\
\hline Б. Рональд 6780909 & 11 & $444,1 \pm 56,78$ & $14107,5 \pm 1202,27$ & $11064,1 \pm 625,12$ & $3,77 \pm 0,085$ & $3,18 \pm 0,023^{1}$ & $414,2 \pm 20,55$ & $351,5 \pm 18,50$ \\
\hline Б. Пагевайр 8641364 & 40 & $340,7 \pm 9,95^{2}$ & $10945,2 \pm 580,46^{2}$ & $9954,7 \pm 457,47^{1}$ & $3,75 \pm 0,036$ & $3,22 \pm 0,016$ & $371,4 \pm 16,18^{1}$ & $319,8 \pm 14,34^{1}$ \\
\hline Г. Тандем 9434213 & 50 & $357,6 \pm 10,78^{2}$ & $10044,2 \pm 528,94^{2}$ & $9110,4 \pm 422,68^{3}$ & $3,78 \pm 0,035$ & $3,23 \pm 0,015$ & $342,4 \pm 15,24^{3}$ & ${ }^{3} 293,3 \pm 13,27^{2}$ \\
\hline Х. Хіатт 60700461 & 17 & $375,1 \pm 31,51^{1}$ & $10890,3 \pm 773,83^{2}$ & $9527,4 \pm 616,51^{1}$ & $3,78 \pm 0,074$ & $3,17 \pm 0,032^{1}$ & $361,1 \pm 25,71^{1}$ & ${ }^{1} 301,4 \pm 19,82^{1}$ \\
\hline Л. Марселлюс 1360 & 4 & $332,0 \pm 19,19^{2}$ & $10418,5 \pm 2340,76$ & $9684,3 \pm 1911,11$ & $3,85 \pm 0,074$ & $3,25 \pm 0,021$ & $372,5 \pm 75,08$ & $313,4 \pm 60,43$ \\
\hline В середньому по лінії & 177 & $374,8 \pm 8,73$ & $11328,0 \pm 308,02$ & $9863,1 \pm 201,34$ & $3,77 \pm 0,019$ & $3,21 \pm 0,008$ & $370,7 \pm 7,42$ & $315,8 \pm 6,32$ \\
\hline Інші батьки & 4 & $415,5 \pm 55,00$ & $10373,3 \pm 1016,31$ & $8794,3 \pm 1304,67$ & $3,65 \pm 0,077$ & $3,17 \pm 0,035$ & $322,4 \pm 51,62$ & $280,1 \pm 43,79$ \\
\hline
\end{tabular}

За кількістю молочного жиру та молочного білка за вищу лактації, як і в попередньому випадку (третя лактація) кращими виявилися потомки бугая Ф. Гайлурона, а гіршими - дочки Е. Найтінгела. Перші за названими ознаками переважали корів, народжених від інших піддослідних бугаїв, на 0,4-61,8 та 1,7-53,6 кг відповідно, однак ця перевага була достовірною лише в $33 \%$ випадків.

Таким чином, аналіз одержаних даних наших результатів свідчить, що показники молочної продуктивності корів суттєво залежать від їх походження за батьком.

Виявлену порівнянням групових середніх зумовленість фенотипової мінливості кількісних ознак мо- лочної продуктивності корів, що походять від різних батьків, підтверджено проведеним нами дисперсійним аналізом (табл. 5). Встановлено, що найсуттєвіший вплив бугаї справляли на надій дочок за першу, другу та третю лактації. Сила впливу батька на цю ознаку у дочок, залежно від лактації, знаходилася в межах 12,9-16,8\% (P < 0,001). Дещо менший вплив плідників справляли на кількість молочного жиру та молочного білка і ще менший - на вміст жиру та білка в молоці. Однак, варто зазначити, що вплив бугаїв на ознаки молочної продуктивності за досліджувані лактації у їх дочок майже у всіх випадках був достовірним (виняток - вміст жиру в молоці за першу лактацію та жиру й білка - за другу та третю лактаціі). 
Таблиця 4

Молочна продуктивність дочок різних бугаїв-плідників за вищу лактацію, $\mathrm{M} \pm \mathrm{m}$

\begin{tabular}{|c|c|c|c|c|c|c|c|c|}
\hline \multirow[b]{2}{*}{ Кличка та інв. № бугая } & \multirow[b]{2}{*}{$\mathrm{n}$} & \multicolumn{7}{|c|}{ Молочна продуктивність } \\
\hline & & $\begin{array}{l}\text { тривалість } \\
\text { лактації, днів }\end{array}$ & $\begin{array}{c}\text { надій за повну } \\
\text { лактацію, кг }\end{array}$ & $\begin{array}{c}\text { надій за } 305 \text { днів } \\
\text { лактації, кг }\end{array}$ & $\begin{array}{l}\text { вміст жиру } \\
\text { в молоці, \% }\end{array}$ & $\begin{array}{l}\text { вміст білка } \\
\text { в молоці, \% }\end{array}$ & $\begin{array}{c}\text { кількість } \\
\text { молочного } \\
\text { жиру, кг }\end{array}$ & $\begin{array}{c}\text { кількість } \\
\text { молочного } \\
\text { білка, кг }\end{array}$ \\
\hline \multicolumn{9}{|c|}{ Лінія К.М.І. Белла 1667366} \\
\hline С. Стейді 7746123 & 26 & $349,2 \pm 16,91^{3}$ & $11690,7 \pm 790,22$ & $10040,0 \pm 397,43$ & $3,81 \pm 0,055$ & $0,018^{1}$ & $382,9 \pm 16,38$ & $=12,17$ \\
\hline Ф. Ломакс 10785322 & 52 & $394,6 \pm 14,62^{3}$ & $11678,6 \pm 536,87$ & $9658,0 \pm 315,64$ & $3,75 \pm 0,042$ & $3,18 \pm 0,013^{1}$ & ${ }^{1} 363,4 \pm 12,89$ & $307,1 \pm 10,01$ \\
\hline Л.М. Мальво 139205420 & 40 & $325,0 \pm 8,96^{3}$ & $10283,1 \pm 418,71^{1}$ & $9649,5 \pm 302,03$ & $3,70 \pm 0,034^{2}$ & $3,16 \pm 0,013^{3}$ & $357,5 \pm 11,68$ & $304,7 \pm 9,81$ \\
\hline Р. Самуело 207184648 & 111 & $455,1 \pm 14,41$ & $11633,9 \pm 297,25$ & $9134,3 \pm 179,21^{2}$ & $3,80 \pm 0,032$ & $3,22 \pm 0,012$ & $346,9 \pm 7,47^{1}$ & $293,9 \pm 5,91^{1}$ \\
\hline В середньс & 229 & 406,6 & $11414,5 \pm 222,50$ & $9446,0 \pm 133,12$ & 3,7 & 3,19 & 356 & $=4,28$ \\
\hline \multicolumn{9}{|c|}{ Лінія С.В.Д. Валіанта 1650414} \\
\hline С. Сідней 9428124 & 67 & $425,3 \pm 17,05^{2}$ & $11292,7 \pm 389,38$ & $9316,8 \pm 247,25^{1}$ & $3,73 \pm 0,033^{1}$ & $3,18 \pm 0,014$ & $348,1 \pm 10,23$ & $295,8 \pm 7,83^{1}$ \\
\hline Роллінгстоунг 103294329 & 96 & $395,6 \pm 10,37^{3}$ & $10918,2 \pm 359,51$ & $9072,2 \pm 223,43^{2}$ & $3,76 \pm 0,024$ & $3,17 \pm 0,010^{3}$ & $341,5 \pm 8,98^{1}$ & $287,4 \pm 7,02^{2}$ \\
\hline Г. Унгут 7352184 & 69 & $439,3 \pm 19,29^{1}$ & $12361,4 \pm 489,50$ & $9744,7 \pm 274,73$ & $3,73 \pm 0,035^{1}$ & $3,17 \pm 0,012^{2}$ & $2363,0 \pm 10,48$ & $309,1 \pm 8,67$ \\
\hline В. Слеман 7817774 & 24 & $379,6 \pm 22,43^{3}$ & $11423,5 \pm 837,37$ & $9821,2 \pm 612,84$ & $3,75 \pm 0,053$ & $3,17 \pm 0,015^{2}$ & $2365,8 \pm 22,14$ & $310,2 \pm 18,73$ \\
\hline К. Бонайр 9324236 & 26 & $387,9 \pm 20,65^{3}$ & 760,58 & $9056,7 \pm 427,44$ & 0,050 & & $15,05^{1}$ & ${ }^{1} 291$, \\
\hline В.Е.Д. Судан 62768990 & 87 & $328,3 \pm 5,86^{3}$ & $10532,9 \pm 215,67^{1}$ & $10002,7 \pm$ & 0,031 & 3,15 & 377 , & 5,85 \\
\hline В середнь & 369 & $391,7=$ & $11190,6 \pm 176,49$ & $9509,4 \pm$ & 3,7 & & 356 & 301 \\
\hline \multicolumn{9}{|c|}{ Лінія Р.О.Р.Е. Елевейшна 1491007} \\
\hline Р. Ба & 59 & 423 , & $746,1 \pm 589,72$ & $9352,2 \pm 310,48^{1}$ & 3,71 & & $20^{1}$ & 298 \\
\hline Г. Твістер 7418701 & 48 & 462,7 & 665,68 & 8930,4 & 3,72 & & $3,91^{1}$ & $11,48^{1}$ \\
\hline Б.Р. Гармоні 9498163 & 56 & 466,5 & 12001 & $9233,0 \pm 280,97^{1}$ & 3,7 & & $0,42^{1}$ & $9,09^{1}$ \\
\hline Л.Х.Ф & 28 & 327, & 45 & $10247,6 \pm 377,01$ & 3, & & 4,53 & 11,16 \\
\hline Ф. Гайлу & 39 & 417,6 & & 10311,7 & & & 4,84 & 20 \\
\hline М. Мані & 56 & $416,3 \pm 1$ & 87 & $2,08^{1}$ & & & 2,83 & 11,04 \\
\hline Е. Найтінг & 91 & $497,1 \pm 2$ & 95 & $8491,7 \pm 1$ & & & $321,9 \pm 7,21^{3}$ & $272,0 \pm 6,07^{3}$ \\
\hline B cepe & 377 & $443,9=$ & $11667,2 \pm 197,45$ & $9237,2 \pm 118,57$ & 3,7 & & 345 & 293,7 \\
\hline \multicolumn{9}{|c|}{ Лінія Х.Х. Старбака 352790} \\
\hline$\overline{\text { Л. K }}$ & 43 & $3,32^{1}$ & $\pm 543,80$ & $10107,3 \pm 336,57$ & & & & \\
\hline В. Сіл & 22 & & & & & & 4,57 & 20,29 \\
\hline С. Клеве & 72 & 425,7 & 04 & $9252,8 \pm 282,68^{1}$ & 39 & $3,17 \pm 0,013^{2}$ & 11,06 & $293,5 \pm 8,99^{1}$ \\
\hline Р.Л. Леген & 28 & 317,4 & $07^{2}$ & $8899,8 \pm 486,53^{1}$ & 51 & $3,15 \pm 0,034^{1}$ & $19,18^{1}$ & $279,1 \pm 14,64^{1}$ \\
\hline 70098604 & 15 & 300 & $\pm 459,39^{1}$ & 1005 & $3,69 \pm 0,044^{1}$ & 3,11 & 16,60 & 13,31 \\
\hline Г. Джунгл 7816598 & 15 & $426,7 \pm 40,36$ & $13445,0 \pm 1387,20$ & $10086,2 \pm 375,20$ & $3,73 \pm 0,074$ & $3,14 \pm 0,019^{3}$ & 18,65 & $316,3 \pm 11,44$ \\
\hline Г. Сам 8324379 & 24 & $412,8 \pm 26,06^{2}$ & $10860,2 \pm 706,55$ & $9004,3 \pm 492,82^{1}$ & $3,79 \pm 0,049$ & $3,20 \pm 0,022$ & $341,9 \pm 19,84$ & $289,1 \pm 16,54$ \\
\hline М. Нірвана 10170 & 67 & $428,5 \pm 17,25^{2}$ & $11357,2 \pm 415,07$ & $9254,7 \pm 261,16^{1}$ & $3,74 \pm 0,026^{1}$ & $3,21 \pm 0,012$ & $346,8 \pm 10,52^{1}$ & $296,9 \pm 8,41^{1}$ \\
\hline В середн & 286 & $411,0 \pm 8,53$ & $11419,7 \pm 222,72$ & $9397,0 \pm 137,48$ & & & $354,4 \pm 5,37$ & $298,8 \pm 4,36$ \\
\hline \multicolumn{9}{|c|}{ Лінія П.Ф.А. Чіфа 1427381} \\
\hline 137002937 & 112 & 410 & $\pm 361,05$ & $10133,8 \pm$ & & & 89 & 6,46 \\
\hline Н. Ардент 137922325 & 43 & $411,1 \pm 22,12^{2}$ & $12311,3 \pm 680,42$ & $10015,4 \pm 346,84$ & $3,76 \pm 0,046$ & $3,19 \pm 0,024$ & 13,15 & $319,7 \pm 11,32$ \\
\hline В.В. Він 139956906 & 88 & $346,4 \pm 7,13^{3}$ & $10237,5 \pm 243,56^{1}$ & $9250,7 \pm 188,34^{1}$ & $3,69 \pm 0,024^{2}$ & $3,16 \pm 0,010^{3}$ & $340,7 \pm 7,08^{2}$ & $291,9 \pm 5,96^{1}$ \\
\hline К.А. Паркер 65258473 & 18 & $302,1 \pm 2,94^{3}$ & $10072,2 \pm 433,59^{1}$ & $9943,6 \pm 424,47$ & $3,71 \pm 0,043^{1}$ & $3,16 \pm 0,021^{1}$ & ${ }^{1} 368,8 \pm 16,84$ & $313,5 \pm 12,87$ \\
\hline М.В. Скотт 7677410 & 47 & $434,6 \pm 26,22$ & $11289,6 \pm 654,62$ & $8801,0 \pm 360,22^{2}$ & $3,85 \pm 0,046$ & $3,17 \pm 0,015^{2}$ & $2339,3 \pm 15,03^{1}$ & $279,5 \pm 11,72^{2}$ \\
\hline 6780909 & 28 & $495,3 \pm 34,14$ & $13151,0 \pm 752,06$ & $9440,9 \pm 397,43$ & $3,76 \pm 0,050$ & $3,18 \pm 0,019$ & $353,3 \pm 14,27$ & $300,2 \pm 12,45$ \\
\hline Б. Пагевайр 8641364 & 109 & $412,7 \pm 13,67^{3}$ & $12332,7 \pm 389,63$ & $9957,0 \pm 216,71$ & $3,74 \pm 0,022^{1}$ & $3,18 \pm 0,010^{2}$ & $372,2 \pm 8,41$ & $315,9 \pm 6,82$ \\
\hline Г. Тандем 9434213 & 104 & $401,8 \pm 11,80^{3}$ & $11616,0 \pm 320,86$ & $9830,3 \pm 212,99$ & $3,74 \pm 0,028^{1}$ & $3,19 \pm 0,010^{1}$ & $1367,1 \pm 8,01$ & $313,3 \pm 6,72$ \\
\hline Х. Хіатт 60700461 & 36 & $=22,19^{1}$ & $11779,0 \pm 601,15$ & $9518,8 \pm 363,12$ & $3,73 \pm 0,044$ & $3,16 \pm 0,020^{2}$ & $354,3 \pm 14,01$ & $300,3 \pm 11,01$ \\
\hline В.Б. Секвойя 64188829 & 36 & $365,5 \pm 15,06^{3}$ & $10977,7 \pm 429,86$ & $9897,5 \pm 324,67$ & $3,69 \pm 0,043^{1}$ & $3,16 \pm 0,019^{2}$ & $366,1 \pm 13,38$ & $312,0 \pm 10,25$ \\
\hline Л. Марселлюс 136057831 & 21 & $397,7 \pm 32,34^{2}$ & $12058,9 \pm 838,35$ & $9694,5 \pm 449,61$ & $3,74 \pm 0,060$ & $3,16 \pm 0,022^{1}$ & $1361,3 \pm 16,75$ & $306,4 \pm 14,21$ \\
\hline В середньому по лінії & 642 & $400,9 \pm 5,36$ & $11711,6 \pm 144,80$ & $9730,4 \pm 84,74$ & $3,75 \pm 0,010$ & $3,18 \pm 0,004$ & $364,2 \pm 3,29$ & $309,0 \pm 2,70$ \\
\hline \multicolumn{9}{|c|}{ Лінія Дж. Бесна 5694028588} \\
\hline & 53 & 317 & $9 \pm 364,10^{2}$ & $9331,5 \pm 345,22$ & & & 34 & 292 \\
\hline Інші батьки & 25 & $322,8 \pm 10,72$ & $10016,5 \pm 308,19$ & $9850.2 \pm 327.20$ & $3.67 \pm 0.034$ & 3 & 362 & $\pm 10,29$ \\
\hline
\end{tabular}

\section{Таблиця 5}

Сила впливу батьків на молочну продуктивність дочок

\begin{tabular}{|c|c|c|c|c|c|}
\hline Ознака & $\eta_{\mathrm{x}}^{2} \pm \mathrm{m}_{\eta}, \%$ & $\mathrm{~F}$ & Ознака & $\eta_{\mathrm{x}}{ }^{2} \pm \mathrm{m}_{\eta}, \%$ & $\mathrm{~F}$ \\
\hline \multicolumn{3}{|l|}{1 лактація } & \multicolumn{3}{|l|}{3 лактація } \\
\hline Число ступенів свободи фактора: організованого & 40 & & Число ступенів свободи фактора: організованого & 28 & \\
\hline неорганізованого & 1940 & & неорганізованого & 531 & \\
\hline Тривалість лактації & $9,9 \pm 2,04^{* * *}$ & 5,3 & Тривалість лактації & $9,3 \pm 5,23^{* *}$ & 1,9 \\
\hline Надій за повну лактацію & $2,9 \pm 2,06^{*}$ & 1,5 & Надій за повну лактацію & $14,2 \pm 5,17^{* * *}$ & 3,1 \\
\hline Надій за 305 днів & $16,8 \pm 2,00^{* * *}$ & 9,8 & Надій за 305 днів & $16,3 \pm 5,13^{* * *}$ & 3,7 \\
\hline Вміст жиру в молоці & $2,5 \pm 2,06$ & 1,3 & Вміст жиру в молоці & $3,7 \pm 5,27$ & 0,7 \\
\hline Вміст білка в молоці & $3,7 \pm 2,06^{* * *}$ & 1,8 & Вміст білка в молоці & $6,6 \pm 5,25$ & 1,3 \\
\hline Кількість молочного жиру & $13,4 \pm 2,02^{* * *}$ & 7,5 & Кількість молочного жиру & $15,6 \pm 5,14^{* * *}$ & 3,5 \\
\hline Кількість молочного білка & $15,4 \pm 2,01^{* * *}$ & 8,8 & Кількість молочного білка & $15,8 \pm 5,14^{* * *}$ & 3,6 \\
\hline \multicolumn{3}{|l|}{2 лактація } & \multicolumn{3}{|l|}{ Вища лактація } \\
\hline Число ступенів свободи фактора: організованого & 34 & & Число ступенів свободи фактора: організованого & 40 & \\
\hline неорганізованого & 1088 & & неорганізованого & 1940 & \\
\hline Тривалість лактації & $5,5 \pm 3,12^{* *}$ & 1,9 & & $11,8 \pm 2,03^{* * *}$ & 6,5 \\
\hline Надій за повну лактацію & $7,0 \pm 3,11^{* * *}$ & 2,4 & & $5,0 \pm 2,06^{* * *}$ & 2,5 \\
\hline Надій за 305 днів & $12,9 \pm 3,07^{* * *}$ & 4,8 & Надій за 305 днів & $4,6 \pm 2,06^{* * *}$ & 2,3 \\
\hline Вміст жиру в молоці & $4,2 \pm 3,12$ & 1,4 & Вміст жиру в молоці & $2,3 \pm 2,06^{*}$ & 1,1 \\
\hline Вміст білка в молоці & $3,8 \pm 3,12$ & 1,3 & Вміст білка в молоці & $4,1 \pm 2,06^{* * *}$ & 2,1 \\
\hline Кількість молочного жиру & $12,4 \pm 3,08^{* * *}$ & 4,5 & Кількість молочного жиру & $4,0 \pm 2,06^{* * *}$ & 2,0 \\
\hline Кількість молочного білка & $12,2 \pm 3,08^{* * *}$ & 4,4 & Кількість молочного білка & $4,3 \pm 2,06^{* * *}$ & 2,2 \\
\hline
\end{tabular}




\section{Висновки}

1. Встановлено, що на формування молочної продуктивності корів значний вплив мають бугаїплідники. Найвищими надоями за 305 днів першої лактації відзначалися дочки бугая Л.Х.Ф. Бая 66821678 , а за другу, третю й вищу лактації - дочки Ф. Гайлурона 103356429, причому обидва бугаї належали до лінії Р.О.Р.Е. Елевейшна 1491007.

2. Найсуттєвіший вплив бугаї справляли на надій дочок за першу-третю лактації (12,9-16,8 \%), дещо менший - на кількість молочного жиру та молочного білка і ще менший - на вміст жиру й білка в молоці.

Перспективи подальших досліджень. У подальшому буде досліджено формування молочної продуктивності корів залежно від племінної цінності їх батьків.

\section{References}

Ilyashenko, H.D., ～\& Polupan, Yu.P. (2009). Vplyv genetychnyh ta paratypnyh chynnykiv na molochnu produktyvnist' koriv ukrai'nskoi' chervonoi' ta chornorjaboi' molochnyh porid. Visnyk stepu, 6, 129-136 (in Ukrainian).

Koval, T.P. (2017). Bugai'-plidnyky ta i'h vplyv na gospodars'ky korysni oznaky koriv dochok napivsester za bat'kom. Rozvedennya i henetyka tvaryn, 53, 124130. doi: 10.31073/abg.53.16 (in Ukrainian).

Lakyn, H.F., 1990. Byometryia: uchebnoe posobye [dlia byol. spets. vuzov]. Moskow, Vysshaia shkola (in Russian).

Pidpala, T.V., \& Bondar, S.A. (2017). Uspadkuvannja selekcijnyh oznak potomstvom bugai'v-plidnykiv golshtyns'koi' porody. Rozvedennya i henetyka tvaryn, 53, 173-179. doi: 10.31073/abg.53.23 (in Ukrainian).

Poslavska, J.V., \& Fedorovych, Y.I. (2015). Molochna produktyvnist' koriv riznyh linij ukrai'ns'koi' chornorjaboi' molochnoi' porody. Naukovyj visnyk L'vivs'kogo nacional'nogo universytetu veterynarnoi' medycyny ta biotehnologij imeni S. Z. G'zhyc'kogo, 17(1), 156-161. https://nvlvet.com.ua/index.php/agriculture/article/view/3 569 (in Ukrainian).

Shulyar, A.L. (2018). The genetic determination of the economically useful characteristics of the cows of ukrainian black-and-white dairy breed. Scientific Messenger of Lviv National University of Veterinary Medicine and Biotechnologies, 20(89), 35-40. doi: 10.32718/nvlvet8906.

Shcherbatyj, Z.Y., \& Bodnar, P.V. (2015). Molochna produktyvnist' koriv ukrai'ns'koi' chorno-rjaboi' molochnoi' porody dochok riznyh golshtyns'kyh bugai'v. Naukovyj visnyk L'vivs'kogo nacional'nogo universytetu veterynarnoi' medycyny ta biotehnologij imeni S.Z. G'zhyc'kogo, 17, 3(63), 347-354. http://nbuv.gov.ua/UJRN/nvlnu_2015_17_3_67 (in Ukrainian).

Stavetska, R., \& Rudyk, I. (2011). Molochna produktyvnist' ukrai'ns'koi' chorno-rjaboi' hudoby: selekcijni osoblyvosti. Tvarynnyctvo Ukrai'ny, 11, 18-22 (in Ukrainian).

Vechorka, V.V., Salogub, A.M., Bondarchuk, V.M., \& Khmelnychyi, S.L. (2018). Realizacija genetychnogo potencialu molochnoi' produktyvnosti bugai'vplidnykiv. Visnyk Sums'kogo nacional'nogo agrarnogo universytetu. Serija "Tvarynnyctvo", 2(34), 30-33 (in Ukrainian). 